\title{
Chapter 19 \\ More than a Century of Biological Control Against Invasive Alien Plants in South Africa: A Synoptic View of What Has Been Accomplished
}

\author{
Martin P. Hill (D, Vincent C. Moran (D), John H. Hoffmann (D), \\ Stefan Neser (D), Helmuth G. Zimmermann (D, David O. Simelane (D, \\ Hildegard Klein (D), Costas Zachariades (D), Alan R. Wood (D), \\ Marcus J. Byrne (D, Iain D. Paterson (D), Grant D. Martin (D), \\ and Julie A. Coetzee
}

\begin{abstract}
Invasive alien plant species negatively affect agricultural production, degrade conservation areas, reduce water supplies, and increase the intensity of wild fires. Since 1913, biological control agents i.e. plant-feeding insects, mites, and fungal pathogens, have been deployed in South Africa to supplement other management practices (herbicides and mechanical controls) used against these invasive plant species. We do not describe the biological control agent species
\end{abstract}

M. P. Hill ( $₫)$ · I. D. Paterson · G. D. Martin

Centre for Biological Control, Department of Zoology and Entomology, Rhodes University,

Makhanda, South Africa

e-mail:m.hill@ru.ac.za

V. C. Moran · J. H. Hoffmann

Department of Biological Sciences, University of Cape Town, Cape Town, South Africa

S. Neser · H. G. Zimmermann · D. O. Simelane · H. Klein

Agricultural Research Council-Plant Health and Protection, Pretoria, South Africa

C. Zachariades

Agricultural Research Council-Plant Health and Protection, Cedara, South Africa

A. R. Wood

Agricultural Research Council-Plant Health and Protection, Stellenbosch, South Africa

M. J. Byrne

Centre for Invasion Biology, School of Animal, Plant and Environmental Sciences, University of the Witwatersrand, Johannesburg, South Africa

Centre for Biological Control, Rhodes University, Makhanda, South Africa

J. A. Coetzee

Centre for Biological Control, Department of Botany, Rhodes University, Makhanda,

South Africa

B. W. van Wilgen et al. (eds.), Biological Invasions in South Africa, Invading

Nature - Springer Series in Invasion Ecology 14,

https://doi.org/10.1007/978-3-030-32394-3_19 
that have been used, or what they do, or how they damage the target plant species. We focus instead on evaluations (informed opinions, evidence and quantifications) of what has been achieved in South Africa by using biological control to suppress populations and impacts of invasive plant species. Satisfactory long-term evaluations of outcomes are difficult and expensive, but many have been done, providing ample evidence that biological control is often highly successful. We use case studies from South Africa to support this assertion and to make the point that successes may be largely forgotten in a relatively short time. Biological control of invasive plants in South Africa is demonstrably cost effective and has become generally accepted as a preferred management strategy. However, it is not a panacea, and we discuss several issues which complicate our understanding of its effectiveness and which raise research and implementation challenges. Further studies are needed on the economic and social benefits of biological control of invasive plants to inform and involve the wider South African community.

\subsection{Introduction}

Biological control of invasive alien plants relies on suitably host-specific natural enemies (agents), mainly plant-feeding insects and mites, and fungal pathogens. The agent species are sourced from their respective countries of origin and released into the invaded range to suppress the aggressiveness of the targeted plant species. The rapid and spectacularly successful outcome of biological control against cactus species, particularly in Australia in the 1930s (Dodd 1940; Mann 1970), set an early precedent suggesting, deceptively, that biological control and the evaluation of its success is easy. This also led, ironically, to the misguided perception that other biological control projects targeting invasive plant species that had less-dramatic outcomes were relative failures. Over the years, unequivocal successes have made up a diminishing proportion of the escalating number of projects that have been initiated, and an increasing number of projects have resulted in significant levels of control, but which have been less obvious and harder to gauge (Raghu and Walton 2007).

Biological control, as a management tool, and as a supplement to physical destruction or removal of the problem plants, and to herbicidal applications, has been used in South Africa since 1913 and has accumulated an impressive number of documented successes (Moran et al. 2005, 2013; Klein 2011; Zachariades et al. 2017). Initially (from 1913 to the 1930s) invasive plants in agriculture, particularly invasive cacti, were the targets of biological control introductions (Zimmermann et al. 2009). Between the 1950s and 1980s, biological control projects were initiated on several species of plants that were invasive in the Cape Floristic Region, a 'biodiversity hotspot', including Hypericum perforatum (Clusiaceae; St. John's Wort; Gordon et al. 1986; Gordon and Kluge 1991), Hakea sericea (Proteaceae; Silky Hakea; Esler et al. 2010; Gordon and Fourie 2011), several Australian Acacia species (Fabaceae; wattles) (Impson et al. 2011), and Leptospermum laevigatum (Myrtaceae; Australian Myrtle; Gordon 2011). This era also saw projects initiated 
against floating, invasive aquatic plants (Coetzee et al. 2011a) and against the various hybrids in the Lantana camara L. hybrid-complex (Verbenaceae; Lantana; Urban et al. 2011). More recently, herbaceous plants, vines and various subtropical shrubs have been subjected to biological control (Moran et al. 2013).

For over a century, South Africa has been one of the five main countries conducting research on and implementation of biological control of invasive alien plants (McFadyen 1998). Since 1995, with major increases in funding from state sources (Zimmermann et al. 2004) and the consequent involvement of many more researchers, students, support staff (see also van Wilgen 2020, Chap. 2, Sect. 2.2), and implementers, there have been an increasing number of innovative and successful projects, allowing South Africa to play a leadership role in the use of biological control in the management of invasive alien plants (Moran and Hoffmann 2015; Schwarzländer et al. 2018).

All the projects and programmes on biological control of invasive plants in South Africa have been thoroughly documented in three sets of reviews (Hoffmann 1991; Olckers and Hill 1999; Moran et al. 2011), in Muniappan et al. (2009), and in a recent overview of the entire South African biological control effort (Zachariades et al. 2017). These compilations have been comprehensive in recording which agents have been sourced, tested, mass-reared, released, established and redistributed against each of the targeted, invasive plant species, and in recording their progress and the extent of damage caused on the target host-plants. However, these accounts have been less clear in summarising the overall achievements (i.e. outcomes) of biological control programmes against invasive alien plant species and consequently, that is the primary purpose of this account.

\subsection{Evaluating the Effectiveness of Biological Control of Invasive Alien Plants}

Across the world, many different approaches have been used to evaluate and express the outcomes of biological control projects against invasive plant species (e.g. Syrett et al. 2000; Morin et al. 2009). It has long been understood that the objective of biological control "... is not the eradication [of the target plant species] but the reduction of their densities to non-economic levels" (Huffaker 1964). In some instances, the success of biological control is self-evident and before-and-after photographic records (see, for example, Figs. 19.1, 19.2 and 19.3) suffice to make the general point. Evaluations of biological control accomplishments against invasive alien plant species, during the earlier eras, were mostly descriptive and subjective. Thus, an apparent understanding of the outcomes of biological control was, and often still is, based on 'proxy-studies' of the progress of the released biological control agents themselves. These studies aligned with the expertise of the scientists involved, who were overwhelmingly entomologists or, less often, pathologists, not plant ecologists. Many of these studies were appropriate for short-term funding cycles and provided excellent subject-matter for post-graduate student projects. 

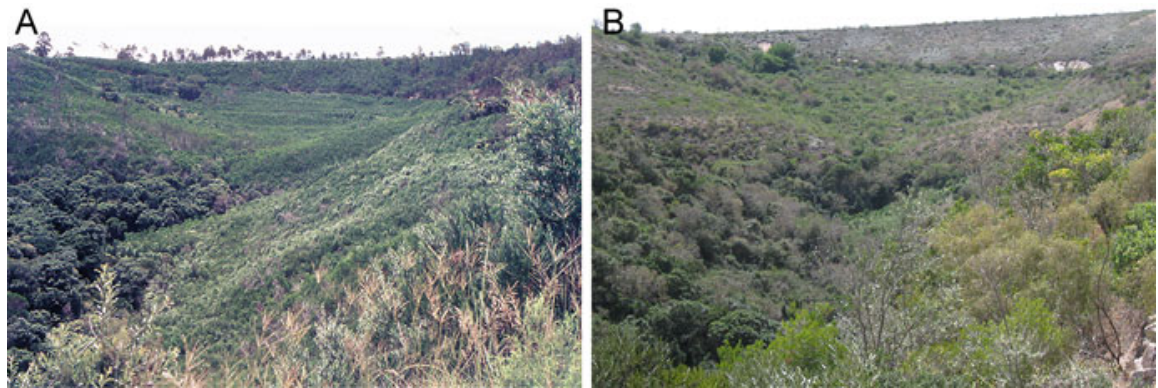

Fig. 19.1 Photographs taken at paired sites near Makhanda, Eastern Cape, before and after successful biological control, on hillsides covered with dense infestations of Acacia longifolia (Long-Leaved Wattle) trees in 1978 (a), subsequently replaced by native vegetation in 2013 (b). Photographs courtesy of JH Hoffmann
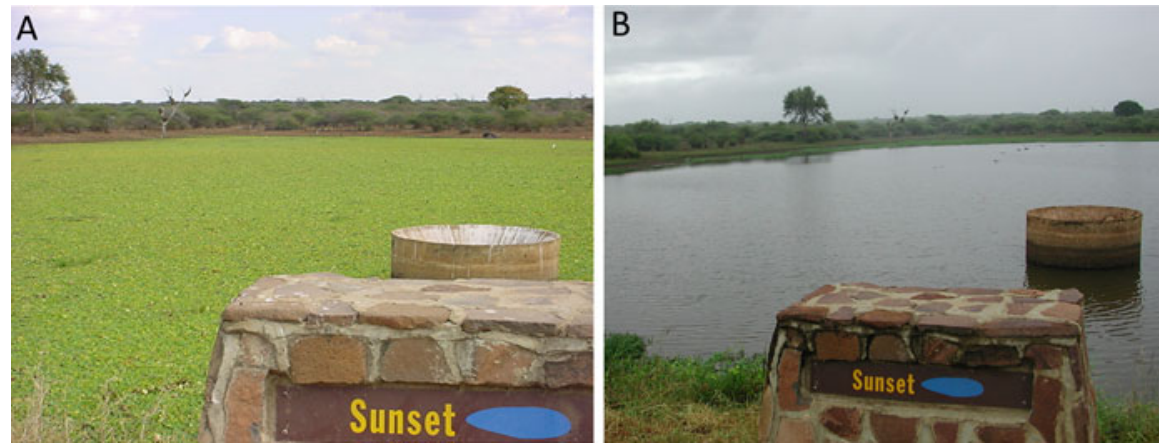

Fig. 19.2 Photographs taken at paired sites on Sunset Dam, Kruger National Park, Mpumalanga, before (a) and after (b) successful biological control of Pistia stratiotes (Water Lettuce). Photographs courtesy of LC Foxcroft
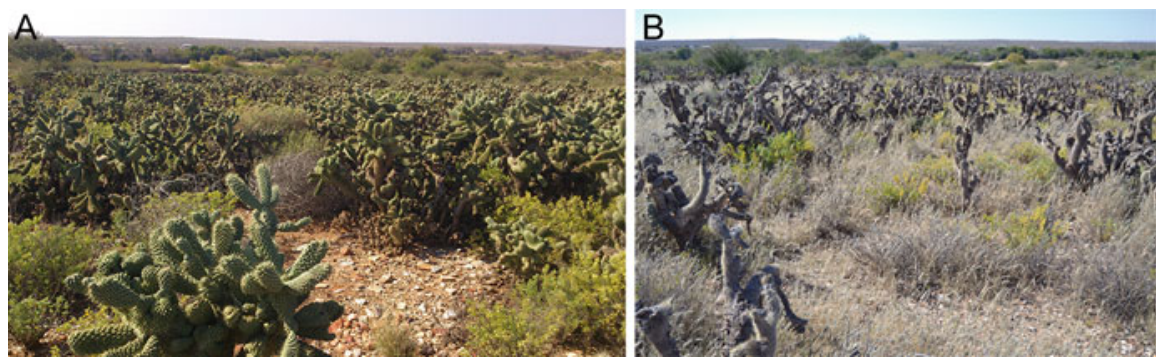

Fig. 19.3 Photographs taken at paired sites near Upington, Northern Cape, of flourishing populations of Cylindropuntia fulgida (Boxing-Glove Cactus) in 2012 (a) replaced by dead and dying stumps in 2015 (b) after biological control. Photographs courtesy of Travor Xivuri 
But Crawley (1989), among others, has emphasised that measures of agent numbers and the levels of damage that they inflict, while useful determinants of progress, are not relevant to the population dynamics of the target plants themselves, i.e. to the outcomes of biological control. This plant-population perspective has been recognised by practitioners and has helped to change the emphasis in assessing the accomplishments of biological control of invasive alien plants.

The outcomes of biological control of invasive alien plants can be measured in many ways, including, for example, reductions in density of the invasive species, the extent of their distribution, changes in biomass, their longevity, and the numbers of seeds, or other propagules, produced and accumulated. Furthermore, as Hoffmann et al. (2019) have noted: "Each of these measures must be considered in a context of scale (e.g. in a defined locality such as a reserve or forest, in a functional habitat such as a river catchment or mountain range, or at a landscape level that might include a biome, region or country)." In the latest world catalogue of biological control of "weeds" (Winston et al. 2014), the "scale of impact" of biological control is categorised by subjective estimates as: "localized, regional, widespread throughout [the] range [of the target plant], and unknown", and descriptive notes are provided to support these opinions for each of 1555 intentional releases of "weed" biological control agents, worldwide. Thus, the impacts of biological control are invariably complex and often site-specific. For example, on Chromolaena odorata (Asteraceae; Triffid Weed), in South Africa, agent-impacts are sporadic and highly localised (Zachariades et al. 2011), and the situation is dynamic and not yet understood (Zachariades et al. 2016). Similarly, on the various taxa in the L. camara hybrid complex, agents undergo 'boom and bust' cycles, dependent on varietal types of the plants, and on altitudinal and other effects (Urban et al. 2011).

For all of these reasons, accurate quantitative measures of plant- and seedpopulation dynamics, and accompanying experimental evaluations of outcomes in biological control, are expensive and difficult, and require years or decades of study. The key here, with more recent South African programmes since the 1970s, has been sustained funding for biological control of invasive plants and the career-longcontinuity of many of the research- and support-personnel involved. This has encouraged long-term research programmes (albeit never enough) and a disproportionately high number of carefully-quantified and unambiguous evaluations. For example: the 25-year evaluation of biological control of Opuntia stricta (Cactaceae; Australian Pest Pear; see Box 19.1) (Hoffmann et al. 1998; Paterson et al. 2011); 16 years of assessment on the biological control of Sesbania punicea (Fabaceae; Red Sesbania) at 22 sites (Hoffmann and Moran 1998); ongoing observations over 28 years on a fungal-pathogen biological control agent used against Acacia saligna (Fabaceae; Port Jackson Willow) (Wood and Morris 2007); continuing country-wide surveys over the past decade on several species of invasive aquatic plants (Coetzee et al. 2011a); and finally, the assessments of the degree of biological control against L. camara, ongoing since the 1970s (Cilliers 1987; Cilliers and Neser 1991; Urban et al. 2011). In all of these cases, and for the other cases cited throughout the text, conclusions about the status of the individual biological control projects, which have 
not been recently or fully published, have been brought up to date (to 2019) from the personal knowledge of one or more of the contributing authors.

\section{Box 19.1 Opuntia stricta (Cactaceae) (Australian Pest Pear)}

Invasion by Opuntia stricta (Australian Pest Pear) in the Kruger National Park was rapid, with about 60,000 ha being infested by the turn of the century, mainly through seeds being spread by baboons and elephants. An intensive herbicide-based control programme failed to achieve its objectives and eventually biological control was adopted as a management process despite the park management's reluctance to have additional non-native species (i.e. biological control agents) brought into a conservation area. Simulation models had correctly predicted that the release of the well-known cactus moth, cactoblastis, in 1988, would result in diminished invasion. But success was mainly due to the release of a cochineal insect species (open circles), in 1997, that kills the pads/ cladodes (closed circles) and the plants. Long-term surveys over 20 years showed that there was a rapid decline in the density of the cactus plants and that the weed has now been permanently controlled well below an acceptable threshold by biological control (Figure updated from Impson et al. 2011).

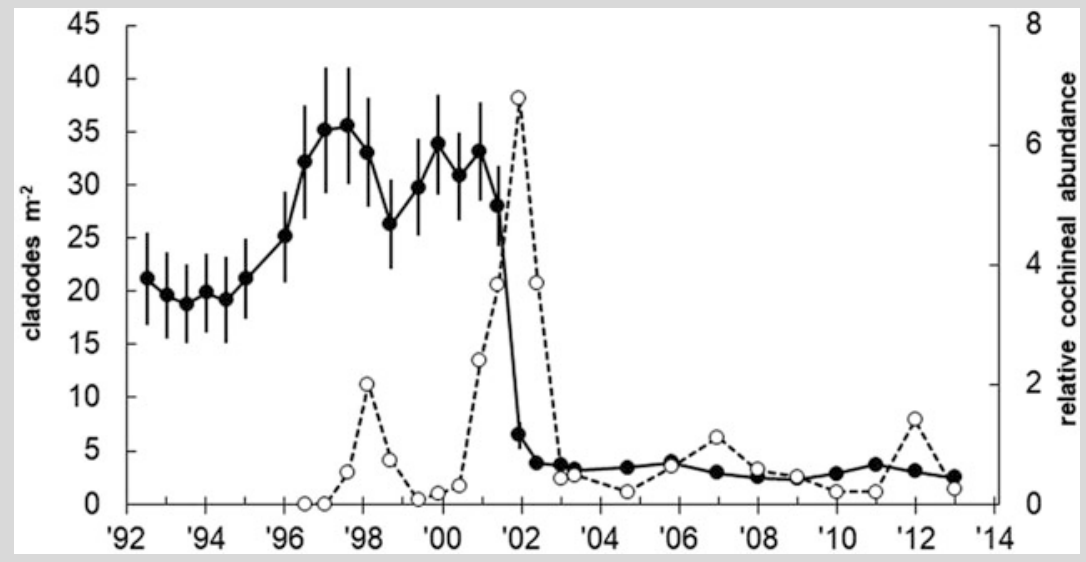

A system has been used in South Africa to describe overall success, i.e. outcomes of biological control against invasive alien plants, at the plant population (demographic) level, as 'complete', 'substantial', 'negligible', or 'unknown', and which relies on long-term formal evaluations, or on expert-opinion on broad categorisations of the reduced dependency on alternative control methods (chemical or mechanical), as a result of the introduction of biological control agents. This classification system was initiated by Hoffmann (1991). It has subsequently been refined and elaborated by Hoffmann (1995), Anonymous (1999), Hoffmann and Moran (2008), Klein (2011) and Zachariades et al. (2017), and has been widely adopted internationally (McFadyen 1998). Using this 'now-traditional' descriptive 
system as a basis, several assessments of the outcomes of biological control of invasive plants in South Africa at the level of a plant population, have been made, including:

1. Hoffmann (1991) who noted that of the 36 invasive plant species subjected to biological control in South Africa at that time, 14\% were under 'complete' control, and $22 \%$ were under 'substantial' control.

2. Later, Klein (2011) recorded that of 48 invasive plant species on which agents had become established in South Africa, 21\% were under 'complete' control and $38 \%$ under 'substantial' control.

3. Zachariades et al. (2017) recorded the following: "Thirteen (72\%) of the 18 worst taxa [of invasive plants in South Africa] from the work of van Wilgen et al. (2012) have biological control agents released on them already, and seven (39\%) of these are under either complete or substantial biological control. When considering the more extensive list of species presented in van Wilgen et al. (2008), a list of 56 most damaging species to ecosystem functioning, 19 (34\%) have active biological control and $13 \%$ are considered to be under substantial control."

4. From the most-recent lists compiled by Zachariades (2018a), counting only those instances in which the agents have been established for more than 10 years (i.e. allowing enough time to draw firm conclusions about outcomes), which coincidently also involves a total of 48 targeted, invasive plant species, $31 \%$ were recorded as under 'complete' control and $40 \%$ under 'substantial' control.

5. Lastly, taking a different approach, Henderson and Wilson (2017) found that there was an approximately $50 \%$ increase in the broad-scale documented range of alien plants in South Africa between 2000 and 2016. But these authors also concluded that "some [invasive plant] species which have been the subjects of successful biological control programmes have shown very little expansion in their distribution" and "in general successful biological control seems to be associated with a reduction in the rate of spread".

A feature of all these summaries is that they are based on the foundation of the 'traditional' system for describing and recording biological control achievements against invasive alien plants. Until now this has been the only way of doing so, but the descriptors and their definitions are vague, often subjective or ambiguous, and convey little or no information about details or context. An elaboration of the present system has therefore been proposed by Hoffmann et al. (2019) which is based on a conceptual framework (see Box 19.2) that categorises the outcomes of biological control, from barely perceptible (category $\mathrm{C}-$ ), to spectacularly successful (categorised as $\mathrm{A}+$ ) where, over decades, the agents have had a considerable impact on one or more of four 'invasion parameters' of their target hosts, namely, plant population density, distribution (area), biomass and number of propagules (seeds), for different regions, habitats or circumstances (see Box 19.3). Other parameters, such as the longevity of invasive plant populations, could be accommodated if required. This system has now been adopted in South Africa, and when implemented it will allow for more nuanced, detailed, and accurate analyses and descriptions of the outcomes of biological control of invasive alien plants. 


\section{Box 19.2 Envisaging the Outcomes of Weed Biological Control}

The sigmoid curve in the figure below (reproduced with permission from Hoffmann et al. 2019) represents the hypothetical extent and progress of an invasion by an alien plant species, commonly measured as either area invaded, density, biomass, seed production or its equivalent. Given time (usually at least 10-20 years) after the initiation of biological control, damage by the biological control agents can reduce target-plant populations and their invasiveness: (1) if the effects are only slight, the trajectory of the curve will be moderated to a greater or lesser degree within the bounds of "control category C'; or (2) as in about $40 \%$ of the cases in South Africa, biological control can 'reverse', i.e. reduce target-plant populations and the extent of the invasion, depressing the trajectory of the curve into 'control category B'; or (3) as in about $30 \%$ of the cases in South Africa, can spectacularly reduce weed populations and the extent of the invasion to levels below a tolerable threshold, moving the curve into 'control category A'. Conceptualising biological control in this way allows for categorisations and subsequent recording of outcomes, from C- (imperceptible levels of control) to A+ (the most favourable outcome), for different regions, habitats, and circumstances. Some examples that illustrate the application of this framework for viewing outcomes in weed biological control are given in Box 19.3.

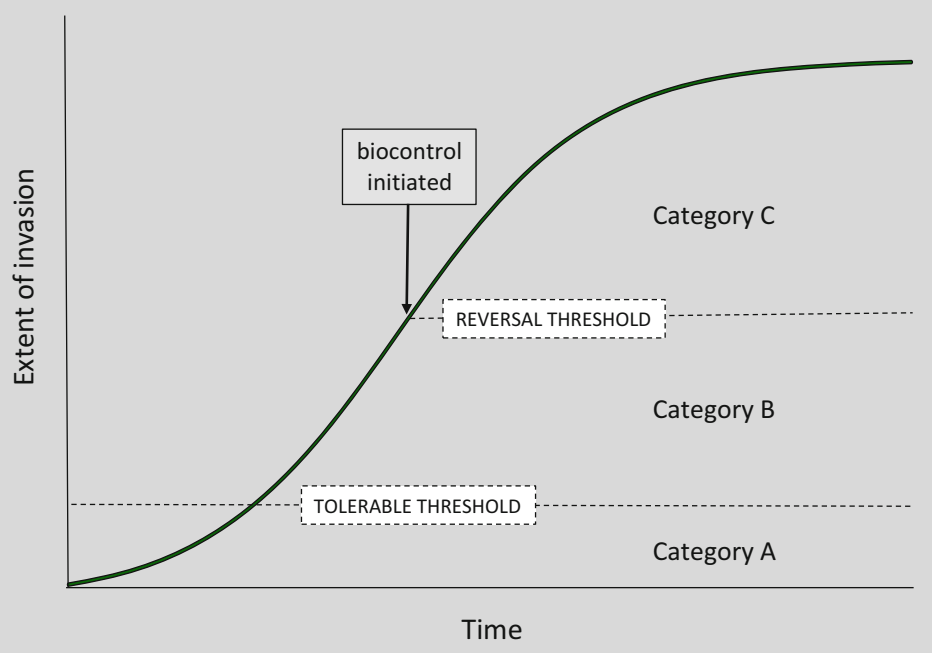




\section{Box 19.3 A System for Recording the Outcomes of Weed Biological Control}

Since the early 1990s, 'complete', 'substantial', or 'negligible' have been accepted descriptions of achievements in weed biological control at the plant population level (i.e. outcomes). These terms are too coarse and therefore can be misleading. For example, a biological control programme might result in the near-elimination ('complete' control), of the target weed in one area or situation, but in 'negligible' control elsewhere, an outcome that would 'average out' as 'substantial' control. This is clearly unsatisfactory. Recently a more elaborate and robust system has been developed for recording outcomes that considers four different 'invasion parameters': density, area, biomass and number of propagules (seeds), for different regions and habitats (Hoffmann et al. 2019). The examples, in the table below, of three well-known South African weed species, illustrate this system. The most positive 'outcomes' are recorded as A+through to $\mathrm{C}-$ as the least favourable, based on categorisations as defined by Hoffmann et al. (2019) (and see Box 19.2). The categorisations that are dependent on expert opinion and observations are in light type, with those supported by quantified evidence in bold type. (1) Opuntia ficus-indica (Mission Prickly Pear), is not under satisfactory biological control in the coastal regions of the Eastern Cape, but is under excellent biological control in drylands, in all other regions, where populations are maintained well below an acceptable threshold. The biological control programme against $O$. ficus-indica has been ongoing for 86 years since the first agent was released against this plant in South Africa. (2) Invasions of Acacia saligna (Port Jackson Willow), in terms of density, biomass and numbers of seeds have been considerably moderated by biological control, but the distribution of the weed has remained static and is characterised by the appearance, over a wide area, of dense mats of seedlings from accumulated seed-banks after a fire or soil-disturbance. (3) Eichhornia crassipes (Water Hyacinth), is under far better biological control in the warmer, coastal areas and in clear waters, than it is in the highlands, under eutrophic conditions.

\begin{tabular}{|c|c|c|c|c|c|c|c|}
\hline \multirow[t]{2}{*}{ Weed species } & \multirow[t]{2}{*}{ Regions } & \multirow[t]{2}{*}{ Habitats } & \multicolumn{5}{|c|}{$\begin{array}{l}\text { Biological control outcomes, over the } \\
\text { years }\end{array}$} \\
\hline & & & Density & Area & Biomass & Seeds & Years \\
\hline $\begin{array}{l}\text { (1) Opuntia ficus-indica } \\
\text { (L.) Mill. (Cactaceae) } \\
\text { Mission Prickly Pear } \\
\text { (Zimmermann and } \\
\text { Moran 1991) }\end{array}$ & $\begin{array}{l}\text { E. Cape } \\
\text { All other }\end{array}$ & $\begin{array}{l}\text { Coastal } \\
\text { Drylands }\end{array}$ & $\begin{array}{l}\mathrm{B}- \\
\mathrm{A}+\end{array}$ & $\begin{array}{l}\mathrm{C}- \\
\mathrm{A}+\end{array}$ & $\begin{array}{l}\mathrm{C}+ \\
\mathrm{A}+\end{array}$ & $\begin{array}{l}\mathrm{C}- \\
\mathrm{A}+\end{array}$ & 86 \\
\hline
\end{tabular}

(continued) 
(2) Acacia saligna (Labill.) H.L.Wendl.

(Fabaceae) Port Jackson Willow (Wood and Morris 2007)

(3) Eichhornia crassipes (C.Mart.) Solms (Pontederiaceae) Water Hyacinth (Coetzee et al. 2011a)

$\begin{array}{lllllll}\text { All } & \text { All } & \text { B } & \text { C } & \text { B+ } & \text { B } & 32\end{array}$

Highlands Eutrophic BHighlands Clear B B- BB - 45 water
B+ + $+\quad \mathrm{B}+$

\section{2} 45

\subsection{What Has Been Forgotten over the Passage of Time?}

One of the idiosyncrasies of biological control of invasive plant species is that society tends to forget the extent and/or intensity of the specific invasions that existed before biological control was implemented and fails to recall that there was ever a problem in the first place. Examples to support this statement and to elaborate on some of the successes achieved, are briefly described below:

1. At the beginning of the last century, Opuntia monacantha (Cactaceae; Cochineal Prickly Pear) was a prominent invasive species along the coastal regions from Cape Town to northern KwaZulu-Natal. Following biological control, populations declined so greatly that $O$. monacantha has become an insignificant and forgotten component of the South African flora. This situation has persisted for over a 100 years since biological control was initiated in 1913 (Lounsbury 1915; Moran et al. 2013).

2. Opuntia ficus-indica (Cactaceae; Mission Prickly Pear) is still considered problematic in some parts of the country. The densities of this plant have however been dramatically reduced over most of its distribution (see Box 19.3), as have its previously devastating socio-economic impacts (Annecke and Moran 1978; Zimmermann and Moran 1991; van Sittert 2002). Prickly-pear has beneficial properties and is used for its fruit and as fodder (Beinart and Wotshela 2011). Currently biological control has suppressed this species to a level at which the benefits of the plant to society now outweigh the costs of the invasion (Shackleton et al. 2007; Zachariades et al. 2017; Zimmermann 2017).

3. In many areas in South Africa, Opuntia aurantiaca (Cactaceae; Jointed Cactus) is under excellent and permanent biological control. But in the Eastern Cape it is still problematic because the species has not been reduced below an acceptable threshold (Moran and Zimmermann 1991), as evidenced by the frequency of complaints from landowners. As has been the case with previous examples, the extent of the invasion prior to biological control has been largely forgotten. The density of $O$. aurantiaca has also been greatly reduced even in the areas where the species is at its worst today (Moran and Annecke 1979; Moran and Zimmermann 1991). 
4. Hypericum perforatum (Clusiaceae; St. John's Wort) became increasingly abundant and problematic in the Western Cape in the mid-1900s, but is now a rarity. Biological control agents that had succeeded in Australia and North America were released in South Africa in the 1960s and 1970s and stopped the invasion of $H$. perforatum at an early stage (Gordon et al. 1986; Gordon and Kluge 1991).

5. The problem of 'short institutional memories' is well illustrated by the example of Sesbania punicea (Fabaceae; Red Sesbania). This plant has been conclusively shown to have been rendered insignificant as an invader through biological control in South Africa (Hoffmann and Moran 1998). Densities of S. punicea declined by more than $95 \%$ as biological control took effect; woodlands of $S$. punicea with closed canopies of $5 \mathrm{~m}$ tall trees with up to $300 \mathrm{~mm}$ basal stemdiameters were reduced to patches of isolated plants that seldom survived long enough to develop beyond small bushy shrubs that are typically under $2 \mathrm{~m}$ tall, with spindly stems. This situation has persisted for the last 40 years, but $S$. punicea is still reported as being troublesome by landowners or landmanagers who are making their own assessments on the extent of the problem for a suspected invasive species that they are encountering for the first time.

6. A variant on the theme discussed in (5) applies to Acacia saligna (Fabaceae; Port Jackson Willow). Dense forests of 5-10 m tall trees with closed canopies and barren understories once covered large areas in the Western Cape. Though still common and plentiful in this province, long-term studies have shown that it is a hugely-reduced problem since biological control was initiated in the late 1980s (Wood and Morris 2007) (see Box 19.3). Observations, since 1991, at 15 sites, some subjected to wild fires, have shown considerable site-specific variations but an overall decrease of more than $60 \%$ in tree densities. Invasive stands now consist predominantly of scattered trees and shrubs, all of which are infected by the pathogenic biological control agent and few will live for more than 5 years. The canopy seldom closes, and therefore other plant species can coexist with A. saligna. Furthermore, A. saligna phyllode biomass and seed outputs have markedly declined (Wood and Morris 2007). Given time, populations will become even less dense and abundant and other control measures will be needed only if landowners must clear their land for immediate use. Yet concerns about $A$. saligna as a highly-problematic invasive species persist.

7. The case study of Acacia longifolia (Fabaceae; Long-Leaved Wattle) is also informative, although there have been no formal quantifications on the changed status of A. longifolia invasions. Before any biological control agents were released, A. longifolia was an abundant and widespread species in the Western Cape. Dennill and Donnelly (1991) had shown that the biological control agents on A. longifolia were prolific and damaging, but there was no attempt to determine how this damage affected the population dynamics of the host plant. Currently, A. longifolia is seldom named, or ranks low on lists of the most-problematic invasive species (Zachariades et al. 2017). It is reasonable to assume that this reversal, i.e. the fact that the plant has all but disappeared from 
the landscape, is principally due to biological control, albeit in conjunction with manual clearing operations, fires and other natural mortalities affecting the seeds. Over 30 years, biological control, and multiple fire cycles, have reversed the aggressiveness of $A$. longifolia which, in most situations, is now generally considered to have been rendered insignificant as an invasive species (Moran and Hoffmann 2012) (see Fig. 19.1).

8. The small serotinous tree, Hakea sericea (Proteaceae; Silky Hakea) is still a problematic invader in the Fynbos Biome, but 50 years ago it was far worse. Extensive clearing and burning operations were pursued in the 1980s and the distribution of dense infestations of hakea declined very significantly (Gordon and Fourie 2011) from about 530,000 ha in 1979 (Fugler 1979) to less than 190,000 ha in 2001 (Grand et al. 2007). The point that may have been overlooked is that these gains were made possible because management practices were backed up by increasing levels of biological control brought about by two species of seed-feeding biological control agents that were first released in South Africa in 1970. Esler et al. (2010), using models developed by Le Maitre et al. (2008), concluded that: "In the virtual absence of mechanical control programs after the mid-1980s, the presence of seed-attacking insects [as biological control agents] provides an explanation for the failure of the previously invading species [i.e. H. sericea] to expand its range"; and that "... biological control was largely responsible for the failure of the species to re-colonize cleared sites, or to spread to new areas following unplanned wildfires."

9. As a result of biological control, and other management efforts, that date back to the mid-1970s, Eichhornia crassipes (Pontederiaceae; Water Hyacinth) is also far less of a problem than it used to be (Coetzee et al. 2011a) (see Box 19.3). In some areas and situations, biological control has completely supressed the species (Hill and Coetzee 2017a). In other areas biological control has significantly reduced plant populations and their impact, so that alternative management methods, such as herbicide applications and manual removal, are required, but far less frequently (Hill and Coetzee 2017b). Biological control of water hyacinth has been hindered by eutrophication of waters that promotes plant growth and by colder climates that slow the development of the insect biological control agents (Hill and Olckers 2001).

10. Other previously-problematic plant species have become uncommon, restricted, or rare under biological control and are now seldom mentioned in discussions on invasive species. Examples include: Ageratina riparia (Asteraceae; Mistflower) (Heystek et al. 2011), Pistia stratiotes (Araceae; Water Lettuce) (Coetzee et al. 2011a) (see Fig. 19.2), Azolla filiculoides (Azollaceae; Red Water Fern) (McConnachie et al. 2004; Hill et al. 2008; Coetzee et al. 2011a), and Myriophyllum aquaticum (Haloragaceae; Parrot's Feather) (see Box 19.4) (Cilliers 1999; Coetzee et al. 2011a). This is also the certain prognosis for Cylindropuntia fulgida var. fulgida (Cactaceae; Chain-Fruit Cholla), and Cylindropuntia fulgida var. mamillata (Cactaceae; Boxing-Glove Cactus), 
both of which are currently being suppressed, over a wide area, to very low levels by biological control (Zimmermann 2017) (see Fig. 19.3).

\section{Box 19.4 Myriophyllum aquaticum (Haloragaceae) (Parrot's Feather)}

Myriophyllum aquaticum (Parrot's Feather) was regarded as one of South Africa's worst aquatic weeds, found in every province, where it caused a reduction in stream flow, blocked water pumps and interfered with recreational activities. Biological control was implemented in 1994 and a survey conducted in 2008 showed that the weed had been eliminated (i.e. 'clear') at $66(63 \%)$ of the 105 sites surveyed (see lower section of 'stack' diagram). Surveys from 1995 to 2017 showed a significant reduction in the density of the weed at the other 39 sites (see lower histogram: mean number of shoots/ $\mathrm{m}^{2} \pm \mathrm{SE}$ ) to levels below a tolerable threshold (Coetzee et al. 2011a)
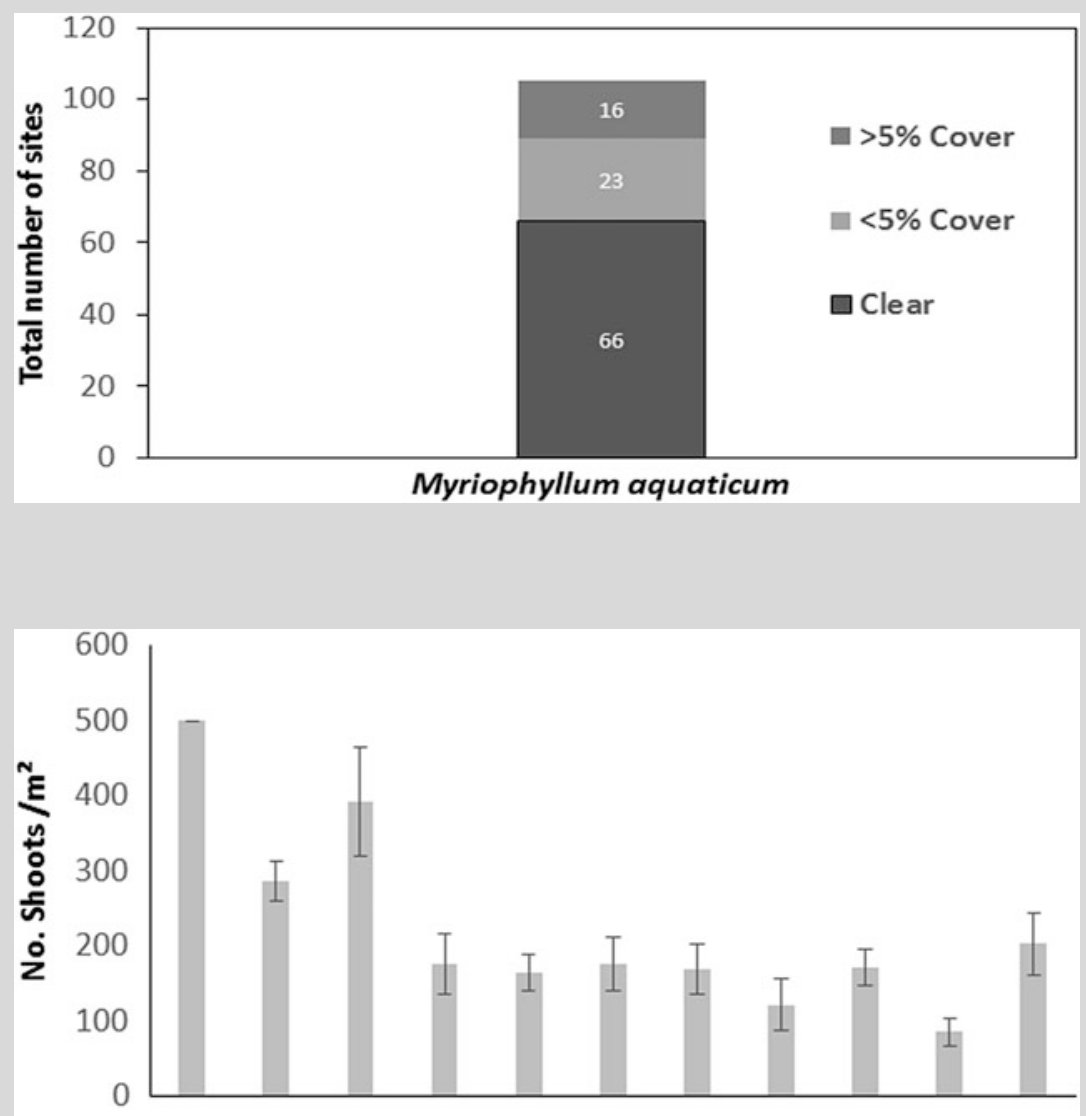

19952008200920102011201220132014201520162017 


\subsection{Additional Considerations, Caveats and Conclusions}

Since 1995, and the advent of support from the Working for Water programme (Zimmermann et al. 2004), biological control of invasive plants in South Africa has gained enormous momentum, and many of the outcomes summarised in this chapter owe their successes to this. Much has been achieved, but some additional points and caveats need to be recorded:

1. Although in this account we have purposely not dealt with the details of the biological control agents that have been used against invasive plant species in South Africa since 1913, all the candidate agents have been subjected to internationally-accepted procedures for safety-testing (usually host-specificity trials): none of the eventual releases have resulted in unexpected consequences, or in damage to non-target plants. Over the years, in South Africa, 70 entities (species and their biotypes) of candidate biological control agents, under consideration in quarantine for prospective use against invasive alien plants, have been 'shelved', i.e. not released pending further developments or investigations, and 65 have been 'rejected' and the cultures destroyed, not usually because of issues with facilities or funding, but because of doubts about their safety (Zachariades 2018b). Klein (2011) has put this into perspective: "It is of particular significance, in terms of safety practices and standards, that all the rejections were advocated and implemented by the researchers themselves, mostly following discussions within the South African weed biological control fraternity. No formal release applications from the researchers have been rejected by the regulatory authorities."

2. An integral feature of the biological control of invasive plants is dealing with conflicts of interest, i.e. where a potential target plant species is problematic in some circumstances or areas, but also has beneficial attributes. Acacia mearnsii De Wild. (Fabaceae; Black Wattle), for example, is a major problem in the Western and Eastern Cape provinces, especially in riparian areas, and was mooted for biological control in the early 1970s. This proposal met with strenuous objections lodged in 1977 by the wattle growers who, in other parts of the country, cultivate $A$. mearnsii and, to a lesser extent, two other closely-related wattle-species as the basis of lucrative timber production and tannin extraction industries. Previous initiatives and experience with other invasive Acacia species in South Africa led to the proposal that seed-destroying agents be released that reduce the reproductive capacity ('invasiveness') of their hosts, but that do not retard the vegetative growth. After protracted discussions and negotiations with the wattle-growers, the first biological control agent was released against A. mearnsii in 1993 (Impson et al. 2011). These precedents explain the frequent use of seed-destroying species in projects for biological control of invasive alien plants in South Africa. In some instances, as with the proposed biological control of two species of invasive Pinus species (Pinaceae; pine trees) in South Africa, attempts at biological control were abandoned, largely because of a failure to overcome conflicts of interest (Moran et al. 2000; Hoffmann et al. 2011). 
3. More emphasis and research efforts are needed on detailed plant-population-level evaluations of the outcomes of biological control. But patience and persistence are the key: too many biological control efforts are perceived as failures because not enough time has elapsed, at least 10 years in many cases (McFadyen 1998), for the agents to have built up sufficiently in numbers and to have had an impact on target-plant populations. For example, an agent released against Pereskia aculeata (Cactaceae; Barbados Gooseberry), at a limited number of sites in South Africa, took 25 years, with numerous interventions to bolster its numbers, before it had a significant impact on its target host.

4. The economic costs and benefits of biological control of invasive plants and gains for agriculture, conservation, ecosystem services, and water supply in South Africa are discussed by van Wilgen et al. (2004), De Lange and van Wilgen (2010), van Wilgen and De Lange (2011), van Wilgen et al. (2012) and by Zachariades et al. (2017). These authors reach consensus that biological control of invasive plants is often more successful than other management practices, is prominently used against some of South Africa's worst invasive species, and is highly cost-effective. Certainly, the interactions of scientists with economists, over the last 25 years, has been crucial in convincing decisionmakers and managers that biological control is essential in efforts to suppress problem plants.

5. Martin et al. (2018) have recently demonstrated the potential for extension of research and implementation practices in biological control of invasive plants to the wider community through employment opportunities and via innovative educational and outreach programmes. These precedents should be more widely applied in biological control and formally assessed for their socio-economic benefits.

6. Biological control is seldom a 'silver-bullet-solution': it is one of several options and strategies for the suppression of invasive alien plants. Early interventions using biological control, before the problem has been allowed to escalate, may maximise the suppression of plant invasions. South Africa has tried to adopt this as an approach for biological control (Olckers 2004) but has not always succeeded, largely because it is difficult to convince funders, landowners, and conservationists to commit resources to an invasive-plant problem that seems trivial and might never materialise.

7. Further, successful biological control is sometimes thwarted because other alien plants replace those that have been controlled. For example, when floating, aquatic invasive plant species are successfully controlled they may be replaced by submerged aquatic invaders (Coetzee et al. 2011b), or in the case of the suppression of invasive Acacia species, they are sometimes replaced by Leptospermum laevigatum (Australian Myrtle) which itself is refractory to biological control (Gordon 2011). Implementation and optimal integration of biological control with other forms of management, and close monitoring to document changes in populations of the invasive and the native flora, following biological control, remain an ongoing challenge and goal for researchers and managers. 
We conclude that even small degrees of suppression of plant fitness, or reductions in the size of populations through biological control will be compounded over the years. In most cases, biological control will reduce the costs of other interventions and will make successful management of the problem more likely and easier. If there are any doubts about what has been achieved with biological control against invasive alien plants in South Africa over the years, the fundamental counterfactual question is: "what would be the extent of the alien plant invasions if there had been no biological controls?'

Acknowledgements Our thanks and respects are extended to past and present invasive plant biological control practitioners in South Africa. Not all of them can be recorded as authors, but their work is the foundation for many of the cases and outcomes reported here. We appreciate the valuable inputs from the reviewers and the editors. We are also grateful to the Working for Water programme of the Department of Water Affairs and Forestry, subsequently the Department of Environmental Affairs, Natural Resources Management Programmes, for their generous financial support since 1995, which has put South Africa in the forefront of endeavours in biological control against invasive alien plants worldwide.

\section{References}

Annecke DP, Moran VC (1978) Critical reviews of biological pest control in South Africa. 2. The prickly pear, Opuntia ficus-indica (L.) Miller. J Entomol Soc South Afr 41:161-188

Anonymous (1999) Appendix. Releases of introduced biological control agents against weeds in South Africa. Afr Entomol Mem 1:175-182

Beinart W, Wotshela L (2011) Prickly pear, the social history of a plant in the Eastern Cape. Wits University Press, Johannesburg. https://doi.org/10.18772/22011115300

Cilliers CJ (1987) The evaluation of three insect natural enemies for the biological control of the weed Lantana camara L. J Entomol Soc South Afr 50:15-34

Cilliers CJ (1999) Biological control of parrot's feather, Myriophyllum aquaticum (Vell.) Verdc. (Haloragaceae), in South Africa. Afr Entomol Mem 1:113-118

Cilliers CJ, Neser S (1991) Biological control of Lantana camara (Verbenaceae) in South Africa. Agric Ecosyst Environ 37:57-75. https://doi.org/10.1016/0167-8809(91)90139-O

Coetzee JA, Hill MP, Byrne MJ et al (2011a) A review of the biological control programmes on Eichhornia crassipes (C.Mart.) Solms (Pontederiaceae), Salvinia molesta D.S.Mitch. (Salviniaceae), Pistia stratiotes L. (Araceae), Myriophyllum aquaticum (Vell.) Verdc. (Haloragaceae) and Azolla filiculoides (Lam.) (Azollaceae) in South Africa. Afr Entomol 19:451-468. https://doi.org/10.4001/003.019.0202

Coetzee JA, Bownes A, Martin GD (2011b) Prospects for the biological control of submerged macrophytes in South Africa. Afr Entomol 19:469-487. https://doi.org/10.4001/003.019.0203

Crawley MJ (1989) Plant life-history and the success of weed biological control projects. In: Delfosse ES (ed) Proceedings of the VII international symposium on biological control of weeds, Rome, 1988. CSIRO, Melbourne, pp 17-26

De Lange WJ, van Wilgen BW (2010) An economic assessment of the contribution of biological control to the management of invasive alien plants and to the protection of ecosystem services in South Africa. Biol Invasions 12:4113-4124. https://doi.org/10.1007/s10530-010-9811-y

Dennill GB, Donnelly D (1991) Biological control of Acacia longifolia and related weed species (Fabaceae) in South Africa. Agric Ecosyst Environ 37:115-135. https://doi.org/10.1016/01678809(91)90142-K 
Dodd AP (1940) The biological campaign against prickly-pear. Commonwealth prickly pear board bulletin. Government Printer, Brisbane

Esler KJ, van Wilgen BW, te Roller KS et al (2010) A landscape-scale assessment of the long-term integrated control of an invasive shrub in South Africa. Biol Invasions 12:211-218. https://doi. org/10.1007/s10530-009-9443-2

Fugler SR (1979) Some aspects of the autecology of three Hakea species in the Cape Province, South Africa. MSc thesis, University of Cape Town

Gordon AJ (2011) Biological control endeavours against Australian myrtle, Leptospermum laevigatum (Gaertn.) F.Muell. (Myrtaceae), in South Africa. Afr Entomol 19:349-355. https:// doi.org/10.4001/003.019.0206

Gordon AJ, Fourie A (2011) Biological control of Hakea sericea Schrad. \& J.C.Wendl. and Hakea gibbosa (Sm.) Cav. (Proteaceae) in South Africa. Afr Entomol 19:303-314. https://doi.org/10. 4001/003.019.0205

Gordon AJ, Kluge RL (1991) Biological control of St. John's Wort, Hypericum perforatum (Clusiaceae), in South Africa. Agric Ecosyst Environ 37:77-90

Gordon AJ, Kluge RL, Neser S (1986) Effect of the gall midge, Zeuxidiplosis giardi (Diptera: Cecidomyiidae), on seedlings of St. John's Wort, Hypericum perforatum (Clusiaceae). In: Delfosse ES (ed) Proceedings of the VI international symposium on biological control of weeds, Vancouver, 1984. Agriculture Canada, Ottawa, pp 743-748

Grand J, Cummings MP, Rebelo TG et al (2007) Biased data reduce efficiency and effectiveness of conservation reserve networks. Ecol Lett 10:364-374. https://doi.org/10.1111/j.1461-0248. 2007.01025.x

Henderson L, Wilson JRU (2017) Changes in the composition and distribution of alien plants in South Africa: an update from the Southern African Plant Invaders Atlas. Bothalia 47(2):a2172. https://doi.org/10.4102/abc.v47i2.2172

Heystek F, Wood AR, Neser S et al (2011) Biological control of two Ageratina species (Asteraceae: Eupatorieae) in South Africa. Afr Entomol 19:208-216. https://doi.org/10.4001/003.019.0208

Hill MP, Coetzee J (2017a) The biological control of aquatic weeds in South Africa: current status and future challenges. Bothalia 47(2):a2152. https://doi.org/10.4102/abc.v47i2.2152

Hill MP, Coetzee JA (2017b) Chapter 7. Biological control of waterhyacinth restores ecosystem functioning to an impoundment in South Africa. In: van Driesche RG and Reardon RC (eds) Suppressing over-abundant invasive plants and insects in natural areas by use of their specialized natural enemies. The Forest Health Technology Enterprise Team (FHTET), FHTET-201702, Morgantown, WV, pp 48-52

Hill MP, Olckers T (2001) Biological control initiatives against water hyacinth in South Africa: constraining factors, success and new courses of action. In: Julien et al (eds) Biological and integrated control of water hyacinth, Eichhornia crassipes. Proceedings of the second global working group meeting for the biological and integrated control of water hyacinth, Beijing, 2000. ACIAR Proceedings, Australian Centre for International Research, Canberra 102: 33-38

Hill MP, McConnachie AJ, Byrne MJ (2008) Azolla filiculoides Lamarck (Pteridophyta: Azollaceae) control in South Africa: a 10-year review. In: Julien MH, Sforza R, Bon MC et al (eds) Proceedings of the XII international symposium on biological control of weeds, La Grande Motte, France, 2007. CAB International, Wallingford, pp 558-560. https://doi.org/10.1079/ 9781845935061.0558

Hoffmann JH (ed) (1991) Introduction. Biological control of weeds in South Africa. Agric Ecosyst Environ 37:1-3. https://doi.org/10.1016/0167-8809(91)90144-M

Hoffmann JH (1995) Biological control of weeds: the way forward, a South African perspective. British Crop Protection Council, Farnham (UK). Weeds in a changing world. Proc Brighton Crop Prot Conf 64:77-89

Hoffmann JH, Moran VC (1998) The population dynamics of an introduced tree, Sesbania punicea, in South Africa, in response to long-term damage caused by different combinations of three species of biological control agents. Oecologia 114:343-348. https://doi.org/10.1007/ s004420050456 
Hoffmann JH, Moran VC (2008) Assigning success in biological weed control: what do we really mean? In: Julien MH, Sforza R, Bon MC et al (eds) Proceedings of the XII international symposium on biological control of weeds, La Grande Motte, France, 2007. CAB International, Wallingford, pp 687-692. https://doi.org/10.1079/9781845935061.0687

Hoffmann JH, Moran VC, Zeller DA (1998) Long-term population studies and the development of an integrated management programme for control of Opuntia stricta in Kruger National Park. South Africa J Appl Ecol 35:156-160. https://doi.org/10.1046/j.1365-2664.1998.00283.x

Hoffmann JH, Moran VC, van Wilgen BW (2011) Prospects for the biological control of invasive Pinus species (Pinaceae) in South Africa. Afr Entomol 19:393-401. https://doi.org/10.4001/ 003.019.0209

Hoffmann JH, Moran VC, Hill MP (2019) Conceptualizing, categorizing and recording the outcomes of biological control of invasive plant species, at a population level. Biol Control. https:// doi.org/10.1016/j.biocontrol.2019.02.005

Huffaker CB (1964) Fundamentals of biological weed control. In: DeBach P, Schlinger EI (eds) Biological control of insect pests and weeds. Chapman and Hall, London, pp 631-649

Impson FAC, Kleinjan CA, Hoffmann JH et al (2011) Biological control of Australian Acacia species and Paraserianthes lophantha (Willd.) Nielsen (Mimosaceae) in South Africa. Afr Entomol 19:186-207. https://doi.org/10.4001/003.019.0210

Klein H (2011) A catalogue of the insects, mites and pathogens that have been used or rejected, or are under consideration, for the biological control of invasive alien plants in South Africa. Afr Entomol 19:515-549. https://doi.org/10.4001/003.019.0214

Le Maitre DC, Krug RM, Hoffmann JH et al (2008) Hakea sericea: development of a model of the impacts of biological control on population dynamics and rates of spread of an invasive species. Ecol Model 212:342-358. https://doi.org/10.1016/j.ecolmodel.2007.11.011

Lounsbury CP (1915) Plant killing insects: the Indian cochineal. Agric J S Afr 1:537-543

Mann J (1970) Cacti naturalized in Australia and their control. Department of Lands, Brisbane

Martin GD, Hill MP, Coetzee JA et al (2018) Synergies between research organisations and the wider community in enhancing weed biological control in South Africa. BioControl 63:437-447. https://doi.org/10.1007/s10526-017-9846-4

McConnachie AJ, Hill MP, Byrne MJ (2004) Field assessment of a frond-feeding weevil, a successful biological control agent of red waterfern, Azolla filiculoides, in southern Africa. Biol Control 29:326-331. https://doi.org/10.1016/j.biocontrol.2003.08.010

McFadyen REC (1998) Biological control of weeds. Annu Rev Entomol 43:369-393. https://doi. org/10.1146/annurev.ento.43.1.369

Moran VC, Annecke DP (1979) Critical reviews of biological pest control in South Africa. 3. The jointed cactus, Opuntia aurantiaca Lindley. J Entomol Soc South Afr 42:299-329

Moran VC, Hoffmann JH (2012) Conservation of the fynbos biome in the Cape Floral Region: the role of biological control in the management of invasive alien trees. BioControl 57:139-149. https://doi.org/10.1007/s10526-011-9403-5

Moran VC, Hoffmann JH (2015) The fourteen international symposia on biological control of weeds, 1969-2014: delegates, demographics and inferences from the debate on non-target effects. Biol Control 87:23-31. https://doi.org/10.1016/j.biocontrol.2015.04.008

Moran VC, Zimmermann HG (1991) Biological control of jointed cactus, Opuntia aurantiaca (Cactaceae), in South Africa. Agric Ecosyst Environ 37:5-27. https://doi.org/10.1016/01678809(91)90136-L

Moran VC, Hoffmann JH, Donnelly D et al (2000) Biological control of alien, invasive pine trees (Pinus species) in South Africa. In: Spencer NR (ed) Proceedings of the X international symposium on biological control of weeds, Bozeman, 1999. Montana State University, Bozeman MT, pp 941-953

Moran VC, Hoffmann JH, Zimmermann HG (2005) Biological control of invasive alien plants in South Africa: necessity, circumspection, and success. Front Ecol Environ 3:71-77. https://doi. org/10.1890/1540-9295(2005)003[0071:BCOIAP]2.0.CO;2 
Moran VC, Hoffmann JH, Hill MP (eds) (2011) Biological control of invasive alien plants in South Africa (1999-2010). Afr Entomol 19:177-549. https://doi.org/10.4001/003.019.0218

Moran VC, Hoffmann JH, Zimmermann HG (2013) 100 years of biological control of invasive alien plants in South Africa: history, practice and achievements. S Afr J Sci 109:5-10. https:// doi.org/10.1590/sajs.2013/a0022

Morin L, Reid AM, Sims-Chilton NM et al (2009) Review of approaches to evaluate the effectiveness of weed biological control agents. Biol Control 51:1-15. https://doi.org/10.1016/j.biocon trol.2009.05.017

Muniappan R, Reddy GVP, Raman A (eds) (2009) Biological control of tropical weeds using arthropods. Cambridge University Press, Cambridge. https://doi.org/10.1017/ CBO9780511576348

Olckers T (2004) Targeting emerging weeds for biological control in South Africa: the benefits of halting the spread of alien plants at an early stage of their invasion. S Afr J Sci 100:64-68

Olckers T, Hill MP (eds) (1999) Biological control of weeds in South Africa (1990-1998). Afr Entomol Mem 1:1-182

Paterson ID, Hoffmann JH, Klein H et al (2011) Biological control of Cactaceae in South Africa. Afr Entomol 19:230-246. https://doi.org/10.4001/003.019.0221

Raghu S, Walton C (2007) Understanding the ghost of Cactoblastis past: historical clarifications on a poster child of classical biological control. Bioscience 57:699-705. https://doi.org/10.1641/ B570810

Schwarzländer M, Moran VC, Raghu S (2018) Constraints in weed biological control: contrasting responses by implementing nations. BioControl 63:313-317

Shackleton CM, McGarry D, Fourie S et al (2007) Assessing the effects of invasive alien species on rural livelihoods: case examples and a framework from South Africa. Hum Ecol 35:113-127. https://doi.org/10.1007/s10745-006-9095-0

Syrett P, Briese DT, Hoffmann JH (2000) Success in biological control of terrestrial weeds by arthropods. In: Gurr G, Wratten S (eds) Biological control: measures of success. Kluwer, Dordrecht, pp 189-230. https://doi.org/10.1007/978-94-011-4014-0_7

Urban AJ, Simelane DO, Retief E et al (2011) The invasive 'Lantana camara L.' hybrid complex (Verbenaceae): a review of research into its identity and biological control in South Africa. Afr Entomol 19:315-348. https://doi.org/10.4001/003.019.0225

van Sittert L (2002) 'Our irrepressible fellow colonist': the biological invasion of prickly pear (Opuntia ficus-indica) in the Eastern Cape, c.1870-c.1910. In: Dovers S, Edgecombe R, Guest B (eds) South Africa's environmental history. Cases and comparisons. David Philip, Cape Town, pp 139-159. https://doi.org/10.1006/jhge.2001.0457

van Wilgen BW (2020) A brief, selective history of researchers and research initiatives related to biological invasions in South Africa. In: van Wilgen BW, Measey J, Richardson DM, Wilson JR, Zengeya TA (eds) Biological invasions in South Africa, Springer, Berlin, pp 31-64. https:// doi.org/10.1007/978-3-030-32394-3_2

van Wilgen BW, De Lange WJ (2011) The costs and benefits of biological control of invasive alien plants in South Africa. Afr Entomol 19:504-514. https://doi.org/10.4001/003.019.0228

van Wilgen BW, de Wit MP, Anderson HJ et al (2004) Costs and benefits of biological control of invasive alien plants: case studies from South Africa. S Afr J Sci 100:113-122

van Wilgen BW, Reyers B, Le Maitre DC et al (2008) A biome-scale assessment of the impact of invasive alien plants on ecosystem services in South Africa. J Environ Manag 89:336-349. https://doi.org/10.1016/j.jenvman.2007.06.015

van Wilgen BW, Forsyth GG, Le Maitre DC et al (2012) An assessment of the effectiveness of a large, national-scale invasive alien plant control strategy in South Africa. Biol Conserv 148:28-38. https://doi.org/10.1016/j.biocon.2011.12.035

Winston RL, Schwarzländer M, Hinz HL et al (eds) (2014) Biological control of weeds: a world catalogue of agents and their target weeds, 5th ed. USDA Forest Service, Forest Health Technology Enterprise Team, Morgantown, WV. FHTET-2014-04 
Wood AR, Morris MJ (2007) Impact of the gall-forming rust fungus Uromycladium tepperianum on the invasive tree Acacia saligna in South Africa: 15 years of monitoring. Biol Control 41:68-77. https://doi.org/10.1016/j.biocontrol.2006.12.018

Zachariades C (2018a) Biological control of invasive alien plants in South Africa: a list of all insects, mites and pathogens released as biological control agents from 1913-2018. http://www. arc.agric.za/arc-ppri/Documents/Table2-NaturalEnemiesReleased.pdf

Zachariades C (2018b) Biological control of invasive alien plants in South Africa: a list of all insects, mites and pathogens considered as biological control agents from 1913-2018. http:// www.arc.agric.za/arc-ppri/Documents/Table1-NaturalEnemiesAll.pdf

Zachariades C, Strathie LW, Retief E et al (2011) Progress towards the biological control of Chromolaena odorata (L.) R.M.King \& H.Rob. (Asteraceae) in South Africa. Afr Entomol 19:282-302. https://doi.org/10.4001/003.019.0229

Zachariades C, Uyi OO, Dube N et al (2016) Biological control of Chromolaena odorata: Pareuchaetes insulata spreads its wings. Proc South Afr Sugar Technol Assoc 89:291-306. https://www.researchgate.net/.../308721341

Zachariades C, Paterson ID, Strathie LW et al (2017) Assessing the status of biological control as a management tool for suppression of invasive alien plants in South Africa. Bothalia 47:2142-2161. https://doi.org/10.4102/abc.v47i2.2142

Zimmermann HG (2017) Global invasions of cacti: control, management and conflicts of interest. In: Inglese P, Mondragon C, Nefzaoui A et al (eds) Crop ecology, cultivation and uses of cactus pear. FAO, Rome, pp 172-185

Zimmermann HG, Moran VC (1991) Biological control of prickly pear, Opuntia ficus-indica (Cactaceae), in South Africa. Agric Ecosyst Environ 37:29-35. https://doi.org/10.1016/01678809(91)90137-M

Zimmermann HG, Moran VC, Hoffmann JH (2004) Biological control in the management of invasive alien plants in South Africa, and the role of the Working for Water Programme. S Afr J Sci 100:34-40

Zimmermann HG, Moran VC, Hoffmann JH (2009) Invasive cactus species (Cactaceae). In: Muniappan R, Reddy GVP, Raman A (eds) Biological control of tropical weeds using arthropods. Cambridge University Press, Cambridge, pp 108-129. https://doi.org/10.1017/ CBO9780511576348.007

Open Access This chapter is licensed under the terms of the Creative Commons Attribution 4.0 International License (http://creativecommons.org/licenses/by/4.0/), which permits use, sharing, adaptation, distribution and reproduction in any medium or format, as long as you give appropriate credit to the original author(s) and the source, provide a link to the Creative Commons licence and indicate if changes were made.

The images or other third party material in this chapter are included in the chapter's Creative Commons licence, unless indicated otherwise in a credit line to the material. If material is not included in the chapter's Creative Commons licence and your intended use is not permitted by statutory regulation or exceeds the permitted use, you will need to obtain permission directly from the copyright holder.

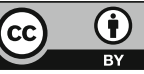

